\title{
Hyvinvointimuutosten taloudelliset vaikutukset kananmunantuotannossa
}

Timo Karhula

MTT Taloustutkimus, Luutnantintie 13, 00410 Helsinki, timo.karhula@mtt.fi

\section{Tiivistelmä}

Suomen Euroopan unionin jäsenyyden seurauksena kananmunatilojen taloudellinen tilanne on varsinkin pienillä tiloilla joutunut muita tuotantosuuntia vaikeampaan asemaan. Tilojen taloudellisen ahdingon lisäksi kanasektorilla on useita muitakin epävarmuutta aiheuttavia tekijöitä, kuten tuotteeseen liittyvät ylituotanto-ongelmat ja markkinahäiriöt, pakkaamotoimintaan liittyvät ongelmat ja kanataloutta koskeviin maataloustukiin liittyvä epävarmuus. Suomen Euroopan unionin jäsenyysaikana kananmunatilojen lukumäärä onkin vähentynyt erittäin voimakkaasti, peräti $70 \%$.

Euroopan unionin neuvoston direktiivi (1999/74/EY) määrittää kananmunantuotantoon käytettävien kanojen suojelua koskevat vähimmäismääräykset. Maa- ja metsätalousministeriö on antanut tähän direktiiviin perustuvan asetuksen (10/EEO/2000) kanojen pidolle asetettavista eläinsuojeluvaatimuksista. Asetus kieltää perinteisten häkkien käytön munivien kanojen pitopaikkana vuoden 2012 alusta alkaen, jolloin häkkituotannosta on siirryttävä virikehäkki- tai lattiakanalatuotantoon tai vaihtoehtoisesti lopetettava kananmunantuotanto kokonaan. Edelleen kuitenkin noin 80 \% kananmunista tuotetaan häkkikanaloissa. Kanojen hyvinvointimuutoksiin perustuvat vaatimukset aiheuttavat kananmunantuottajille suuria investointeja aivan lähitulevaisuudessa, jos tiloilla aiotaan jatkaa tuotantoa vuoden 2012 jälkeen.

Investoinnit virikehäkkeihin tai lattiakanaloihin muodostuvat tiloille kalliiksi ja lisäävät riskejä epävarmassa toimintaympäristössä. Kananmunien tuotantokustannuksen on arvioitu nousevan hyvinvointimuutosten seurauksena keskimäärin $0,30 € / \mathrm{kg}$. Tuotot eivät riitä ennen eivätkä varsinkaan investointien suorittamisen jälkeen kattamaan tuotantokustannuksia. Häkkikanaloista luopumisen myötä työvaltaisempaan teknologiaan siirtymisen seurauksena tuottojen ja tuotantokustannusten erotus kasvaa edelleen ja siten tilojen kannattavuus laskee. Ellei kananmunan hinta käänny nousuun, kananmunantuottajien on tingittävä tulevaisuudessa tuntipalkastaan vielä noin kaksi euroa.

Suomessa kananmunantuotannon asema on jo nyt hyvin haastava ja tulevaisuudessa sektorilla tullee olemaan suuria muutoksia ja ongelmia. Heikosti kannattavilta tiloilta vaaditaan investointeja kanojen hyvinvoinnin edistämiseksi ja samalla odotetaan myös investointeja rakennekehityksen nimissä. Suoritetut investoinnit kuitenkin pakottavat jatkamaan tuotantoa pitkään, vaikka taloudelliset toimintaedellytykset heikkenisivät ja toimintaympäristö muuttuisi. Oman epävarmuutensa sektorille tuovat maatalouspoliittiset uudistukset. Kananmunantuottajat ovatkin reagoineet epävarmaan toimintaympäristöön, sillä noin puolet kananmunantuottajista harkitsee luopuvansa tuotannosta lähitulevaisuudessa. Tutkimuksen valossa kananmunantuottajien investointihaluttomuus ja tuotannosta luopumisinnokkuus ovat hyvin ymmärrettävissä.

Asiasanat: kananmunantuotanto, hyvinvointimuutokset, tuotantokustannus, kannattavuus 


\section{Johdanto}

Suomen Euroopan unionin jäsenyyden seurauksena kananmunatilojen taloudellinen tilanne on varsinkin pienillä tiloilla joutunut muita tuotantosuuntia vaikeampaan asemaan. Tilojen taloudellisen ahdingon lisäksi kananmunasektorilla on ollut useita muitakin epävarmuutta aiheuttavia tekijöitä, kuten tuotteeseen liittyvät ylituotanto-ongelmat ja markkinahäiriöt, pakkaamotoimintaan liittyvät ongelmat ja kanataloutta koskeviin maataloustukiin liittyvä epävarmuus.

Suomen Euroopan unionin jäsenyysaikana kananmunatilojen lukumäärä on vähentynyt peräti 70 \%. Siten vuonna 2005 päätuotantosuuntanaan kananmunantuotantoa harjoittavia tiloja oli enää noin 530 kappaletta. Kananmunatilojen lukumäärä on kuitenkin noussut suurissa tilakokoluokissa, mutta vähentynyt erittäin voimakkaasti pienissä tilakokoluokissa. Sektorilla on siten tapahtunut rakennekehitystä, mutta edelleen Suomen kananmunatilojen tilakoko on EU- maiden pienimpiä. Kanojen lukumäärä on jäsenyyden aikana laskenut kuitenkin vain noin $20 \%$, mutta kanat keskittyvät entistä enemmän suuriin tilakokoluokkiin.

Euroopan unionin neuvoston direktiivi (1999/74/EY) määrittää kananmunantuotantoon käytettävien kanojen suojelua koskevat vähimmäismääräykset. Maa- ja metsätalousministeriö on antanut tähän direktiiviin perustuvan asetuksen (10/EEO/2000) kanojen pidolle asetettavista eläinsuojeluvaatimuksista. Asetus kieltää perinteisten häkkien käytön munivien kanojen pitopaikkana vuoden 2012 alusta alkaen, jolloin häkkituotannosta on siirryttävä virikehäkki- tai lattiakanalatuotantoon tai vaihtoehtoisesti lopetettava kananmunantuotanto kokonaan. Suomessa perinteisissä häkkikanaloissa tuotetaan kuitenkin edelleen liki 80 \% munista. Kanojen hyvinvointimuutoksiin perustuvat vaatimukset aiheuttavat kananmunantuottajille suuria investointeja aivan lähitulevaisuudessa, jos tiloilla aiotaan jatkaa tuotantoa myös tulevaisuudessa. Hyvinvointimuutoksiin kohdistuvat investoinnit ovat kuitenkin olleet hyvin vähissä sektorille kohdistuvien epävarmuustekijöiden ja sektorin alhaisen kannattavuuden vuoksi.

Tutkimuksessa on tarkastelu kananmunatilojen taloudellista tilannetta ja hyvinvointimuutosten taloudellisia vaikutuksia.

\section{Aineisto ja menetelmä}

Tutkimuksessa aineistona on käytetty MTT Taloustutkimuksen kannattavuuskirjanpitotila-aineistoa (FADN) kananmunatilojen osalta vuosilta 2000 - 2005. Kananmunatilaksi on luettu tilat, joilla on munituskanoja yli 500 kappaletta ja kananmunista saatava tuotto on yli $30 \%$ kokonaistuotosta. Näillä kriteereillä kananmunatiloja on aineistossa 8 - $15 \mathrm{kpl}$ riippuen tilivuodesta.

Hyvinvointimuutosten talousanalyysia varten laadittiin neljä eri mallia, joista kukin kahdella eri investointimeno-olettamalla. Mallien lähtötiedot perustuvat kannattavuuskirjanpitotila-aineistoon, tutkimuksen tilaseurannan tuottamiin tuloksiin ja työnkäyttöä selvittäviin tutkimuksiin sekä muihin lähteisiin. Malleissa on mukana hyvinvointivaatimukset täyttävät tuotantotapamallit (virikehäkki- tai lattiakanalatuotanto) ja lisäksi yhdistetyt tuotantotapa- ja kanalarakennusmallit. Yhdistetyt mallit kuvaavat tilannetta, jos vanhat kanalarakennukset eivät sovellu hyvinvointimuutosten edellyttämiin tila- ja tuotantojärjestelyihin.

Taulukko 4. Hyvinvointimuutosten tarkastelussa käytettävät mallit.

\begin{tabular}{|l|c|l|l|}
\hline Mallin kuvaus & $\begin{array}{l}\text { Virikehäkkien } \\
\text { investointimeno } \\
€ / \text { kana }\end{array}$ & $\begin{array}{l}\text { Lattiakanalan inves- } \\
\text { tointimeno } \\
€ / \text { kana }\end{array}$ & $\begin{array}{l}\text { Rakennuksen } \\
\text { investointimeno } \\
€ / \text { kana }\end{array}$ \\
\hline Virikehäkit & $15-20$ & $13-15$ & \\
\hline Lattiakanala & $15-20$ & & $13-15$ \\
\hline Virikehäkit ja rakennus & & $13-15$ & $15-20$ \\
\hline Lattiakanala ja rakennus & & & \\
\hline
\end{tabular}




\section{Tulokset}

Investoinnit virikehäkkeihin tai lattiakanaloihin muodostuvat kananmunatiloille kalliiksi ja lisäävät riskejä epävarmassa toimintaympäristössä. Siirryttäessä virikehäkki- tai lattiakanalatuotantoon tilojen työmäärä tulee kasvamaan arvion mukaan noin $10 \%$ ja investointimenoja pelkistä hyvinvointimuutoksista kertyy 13 - $20 € /$ kana. Tämän lisäksi uuden tuotantorakennuksen rakentaminen tulee maksamaan suunnilleen yhtä paljon, jos vanhat kanalarakennukset pitää korvata uusilla.

Kanojen hyvinvointimuutokset nostavat kananmunatilojen tuotantokustannusta keskimäärin 0,30 $€ /$ kg. Tuotettua munakiloa kohden tuotantokustannukseksi muodostuu hyvinvointimuutosten jälkeen keskimäärin 1,90 €/kg. Ennen hyvinvointimuutoksia tuotantokustannukset ovat olleet keskimäärin 1,60 €/kg. Tuotantokustannukset nousevat vähemmän $(0,20 € / \mathrm{kg})$, jos hyvinvointimuutosten toteuttamiseksi ei tarvitse rakentaa uutta kanalarakennusta. Toisaalta kanalarakennuksen rakentaminen tulee tiloille erittäin kalliiksi, sillä se nostaa hyvinvointimuutoksineen tuotantokustannusta noin $0,40 € / \mathrm{kg}$. Suurilla tiloilla tuotantokustannukset ovat pieniä tiloja alhaisempia sekä ennen että jälkeen hyvinvointimuutosten.

Kananmunatiloilla tuotot säilyvät samalla tasolla hyvinvointimuutoksista huolimatta, sillä kananmunan hinta ei muutu tuotantotavasta riippuen ja tukitasojen on oletettu säilyvän malleissa ennallaan. Tuotot ovat olleet keskimäärin $1,50 € / \mathrm{kg}$, joten tuotot eivät riitä kattamaan tuotantokustannusta ennen eivätkä hyvinvointimuutosten suorittamisen jälkeen. Ennen hyvinvointimuutoksia muodostuukin yrittäjäntappiota keskimäärin 0,10 €/kg ja investointien suorittamisen jälkeen keskimäärin 0,40 €/kg, joten syntyvän yrittäjäntappion määrä kasvaa hyvinvointimuutosten myötä. Kananmunantuottajien onkin tingittävä jo nykytilanteessa taloudellista tavoitteistaan ja hyvinvointimuutosten seurauksena tavoitteista on tingittävä vielä lisää.

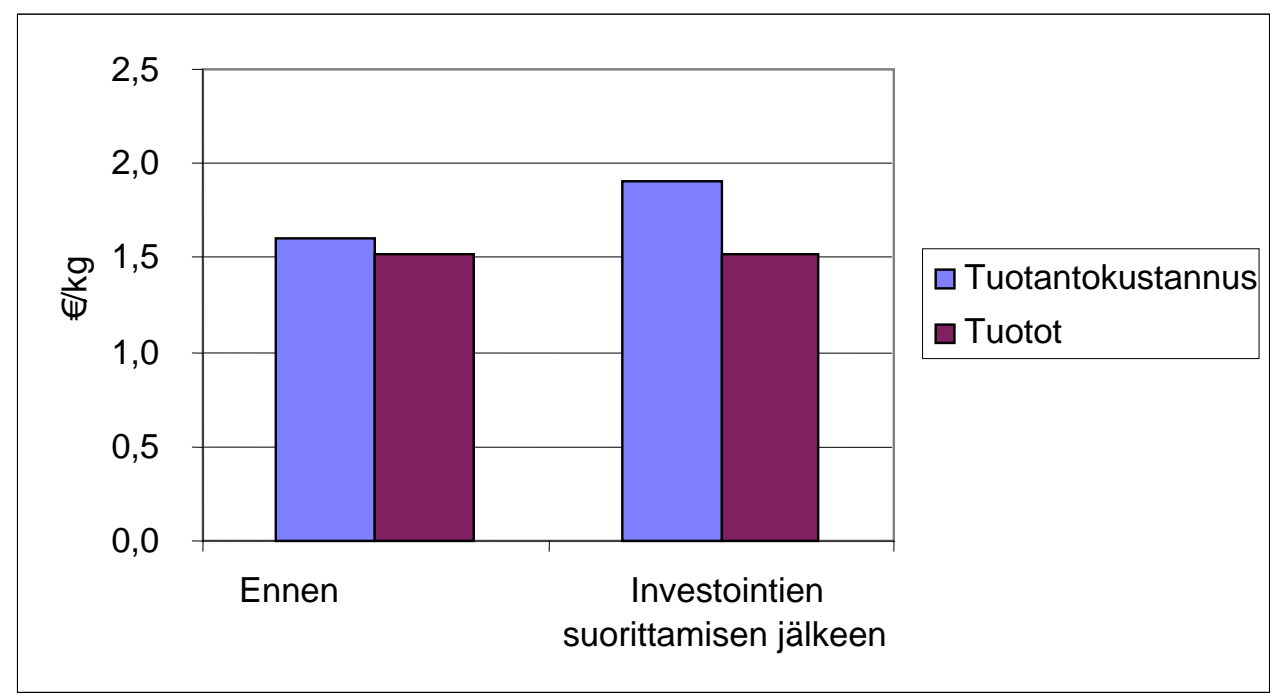

Kuva. Hyvinvointimuutosten vaikutus tuottoihin ja tuotantokustannukseen (€/kg).

Kananmunatilojen taloudellinen tilanne on heikentynyt 2000-luvulla merkittävästi. Tilojen kannattavuuskerroin oli vuonna 2000 vielä 1,2, mutta jo vuoteen 2005 mennessä kannattavuus on heikentynyt yli puolella. Tämä tarkoittaa sitä, että maataloustyöntekijän keskituntiansion sijaan kananmunantuottajalle jäi vuonna 2005 palkaksi vain $6 €$ /työtunti ja 2,5 \%:n korkotuotto omalle pääomalle.

Kanojen hyvinvointimuutokset laskevat kananmunantuotannon kannattavuutta edelleen. Arvion mukaan kannattavuuskerroin laskee hyvinvointimuutosten seurauksena keskimäärin 0,2 yksikköä, mikä merkitsee kananmunantuottajien tuntipalkan laskua vielä noin kahdella eurolla ja oman pääoman korkovaatimuksen pienentymistä noin yhdellä prosentilla. Hyvinvointimuutokset laskevat kannattavuutta sekä pienillä että suurilla tiloilla. Suurilla tiloilla kannattavuus jää kuitenkin pieniä tiloja korkeammalle tasolle hyvinvointimuutosten suorittamisen jälkeen, koska niillä kannattavuus on jo lähtötilanteessa parempi. Etenkin pienille tiloille kannattavuuden heikkeneminen tulee olemaan ongelmallista, koska niillä kannattavuus on jo ennen hyvinvointimuutoksia heikkoa. 


\section{Johtopäätökset}

Suomessa kananmunantuotannon asema on haastava. Heikon kannattavuuden lisäksi tiloilta odotetaan investointeja kanojen hyvinvoinnin ja myös rakennekehityksen edistämiseksi. Kananmunantuotannon rakennekehitykselle on olemassa kuitenkin suoranaista tarvetta, mikäli haluamme pysyä kananmunantuotannon osalta kilpailukykyisinä ja taata kotimaisten kananmunien tarjonnan. Suomen EU-jäsenyyden aikana kananmunatilojen rakenne on toki kehittynyt suurempaan ja erikoistuneempaan tuotantoon, mutta muualla Euroopassa rakennekehitys on edennyt nopeammin askelin.

Hyvinvointimuutosten seurauksena perinteisistä häkkikanaloista on luovuttava ja siirryttävä hyvinvointivaatimukset täyttäviin tuotantotapoihin. Hyvinvointimuutosinvestointien myötä ja työvaltaisempaan teknologiaan siirtymisen seurauksena tuottojen ja tuotantokustannusten erotus kuitenkin kasvaa edelleen, jolloin kananmunatilojen kannattavuus laskee. Tuotot eivät riitä ennen eivätkä varsinkaan investointien jälkeen kattamaan tuotantokustannuksia. Ellei kananmunan hinta käänny mahdollisten tuotantosupistusten myötä nousuun, on kananmunantuottajien tingittävä tulevaisuudessa taloudellista tavoitteistaan vielä lisää. Kananmunantuottajien kannalta tilanne on kestämätön.

Kanojen hyvinvointimuutoksiin liittyvillä investointivaatimuksilla voidaan nähdä olevan selvä vaikutus kananmunatilojen lukumäärän vähentymiseen. Tilojen määrä tulee laskemaan vielä hyvin merkittävästi, sillä noin puolet tuottajista on ilmoittanut harkitsevansa tuotannon lopettamista. Etenkin pienet kananmunatilat tulevat luopumaan tuotannosta, sillä niillä kannattavuus on jo ennen hyvinvointimuutoksiin tähtääviä investointeja heikkoa. Suurilla tiloilla on kuitenkin paremmat mahdollisuudet selvitä hyvinvointimuutoksista, sillä niillä kannattavuus on korkeammalla tasolla sekä ennen että jälkeen hyvinvointimuutosten. Kananmunantuotannon vähentymisellä voi olla tulevaisuudessa tuotemarkkinoita tasapainottava vaikutus.

Suomessa kananmunantuotannon asema on jo nyt hyvin haastava ja tulevaisuudessa sektorilla tullee olemaan suuria muutoksia ja ongelmia. Heikosti kannattavilta tiloilta vaaditaan investointeja kanojen hyvinvoinnin edistämiseksi ja samalla odotetaan myös investointeja rakennekehityksen nimissä. Suoritetut investoinnit kuitenkin pakottavat jatkamaan tuotantoa vuosikausia tai jopa vuosikymmeniä, vaikka taloudelliset toimintaedellytykset heikkenisivät ja toimintaympäristö muuttuisi. Oman epävarmuutensa sektorille tuovat lukuisat muutkin tekijät, mm. maatalouspoliittiset uudistukset ja kustannusten viimeaikainen raju nousu. Tutkimuksen valossa kananmunantuottajien investointihaluttomuus ja tuotannosta luopumisinnokkuus ovat siten hyvin ymmärrettävissä.

\section{Kirjallisuus}

10/EEO/2000. Kanojen pidolle asetettavat eläinsuojeluvaatimukset. Maa- ja metsätalousministeriö. Asetus.

1999/74/EY. Munivien kanojen suojelun vähimmäisvaatimukset. Euroopan unioni. Neuvoston direktiivi. 